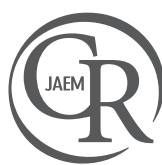

\section{High Fever- Dyspnea: Diagnosis of AIDS in the Emergency Department}

\author{
Yüksek Ateş Nefes Darlığl: Acil Serviste AIDS Tanısı
}

\author{
Okhan Akdur, Serdar Can, Göksu Afacan
}

Department of Emergency Medicine, Faculty of Medicine, Çanakkale Onsekiz Mart University, Çanakkale, Turkey

\section{ABSTRACT}

Cases with human immunodeficiency virus (HIV) may present at the emergency departments at any stage of the disease. We have presented a patient presenting with acute onset of weakness, dysphagia, cough and hoarseness, who was subsequently diagnosed as pneumonia and AIDS. A fifty-year-old male patient presented at the emergency department with symptoms of generalized weakness, high fever, dysphagia and hoarseness of acute onset. The respiration rate was $35 / \mathrm{min}$, body temperature: $38.8^{\circ} \mathrm{C}$, pulse: $110 / \mathrm{min}$, and $\mathrm{O}_{2}$ saturation: $88 \%$. On physical examination, sores with white plaques were found in the oral mucosa and pharynx. In both lungs, auscultation revealed rales in the basal regions. Chest $X$-Ray revealed consolidation in the basal regions of both lungs. Considering all the clinical findings, a clinical state was thought to be causing pneumonia on the basis of immune suppression, and the Anti-HIV test was requested. Upon a positive test result, the patient was hospitalized with the diagnoses of pneumonia and AIDS. The patient was followed up at the intensive care unit and died due to respiratory failure. AIDS is the first disease to be suspected and confirmed in cases presenting at the emergency departments with non-specific symptoms, together with a potential of immune suppression.

Keywords: Adult, acquired immune deficiency syndrome, symptoms and signs

Received: 19.06.2012 Accepted: 22.07.2012

\section{ÖZET}

Insan immün yetmezlik virüslü (HIV) olgular, Acil Servislere hastalığın herhangi bir evresinde başvurabilirler. Bizde acil servisimize ani başlayan güçsüzlük, yutma güçlüğü, öksürük ve ses kısıklığı şikayetleri ile başvuran, sonrasında pnömoni ve AiDS tanısı alan bir olguyu sunduk. Elli yaşında erkek hasta ani başlayan yaygın güçsüzlük, yüksek ateş, yutma güçlüğü, öksürük ve ses kısıklığı şikayeti ile acil servisimize başvurdu. Solunum sayısı 35/dk, vücut ISISI $38.8^{\circ} \mathrm{C}$, nabzı 110/dk, $\mathrm{O}_{2}$ saturasyonu \%88 idi. Fizik muayenede, oral mukozada ve farenkste beyaz plaklanma gösteren yaralar mevcuttu. Her iki akciğer oskültasyonunda bazallerde raller mevcuttu. Akciğer grafisinde her iki akciğer bazallerinde konsolidasyon tespit edildi. Klinik bulguların tümü göz önüne alındığında immun kompresyon zemininde pnömoni yaratan bir klinik durum olabileceği düşünülerek Anti-HIV testi istenildi. Test sonucu pozitif gelmesi üzerine pnömoni ve AiDS tanıları ile yatırıldı. Yoğun bakım takip edilen hasta solunum yetmezliği nedeniyle kaybedildi. AIDS hastalığı non spesifik semptomlar ile acil servise başvuran ancak potansiyel bir immün baskılanma durumunda şüphelenildiğinde akla gelmesi gereken ve doğrulanması gereken bir tanıdır.

Anahtar Kelimeler: Erişkin, kazanılmış bağışıklık yetersizliği sendromu, semptomlar ve bulgular

Geliş Tarihi: 19.06.2012 Kabul Tarihi: 22.07.2012

\section{Introduction}

Cases with human immunodeficiency virus (HIV) may present at the Emergency departments at any stage of the disease (1). Involvement of all vital organs may be seen in the clinical course of AIDS. According to the 2006 data, the estimated number of adult HIV/Acquired immune deficiency syndrome (AIDS) cases is approximately 39.5 million worldwide. In the United States, most of the diagnosed cases are adult men (2). In Turkey, 48 AIDS and 142 HIV cases were reported to the Ministry of Health in 2002, while the corresponding figures in 2010 were determined as 70 cases of AIDS and 557 HIV infections (3). Turkey is ranked among countries with a low prevalence of HIV/AIDS. However, notification and recording of the disease has been suggested to be insufficient in our country. 
The course of AIDS is characterized by non-specific symptoms such as fever, weight loss, malaise and anorexia. Therefore, it may be confused with infectious diseases, cancer and drug reactions. In rare cases, these patients are initially diagnosed at the emergency departments $(4,5)$.

In this case report, we have presented a patient presenting with acute onset of weakness, dysphagia, cough and hoarseness, who was subsequently diagnosed as pneumonia and AIDS, and we evaluated the case as per related literature.

\section{Case Report}

A fifty-year-old male patient presented at the emergency department with symptoms of generalized weakness, high fever, dysphagia and hoarseness of acute onset. His medical history revealed follow-up in another healthcare center with the pre-diagnosis of pneumonia and a mass in the lung of about 2 months duration and he presented at our emergency department following an increase of symptoms. The medical history was negative in terms of any known disease; he had smoked 4 packs/day for 10 years and a weight loss of approximately $20 \mathrm{~kg}$ was observed in the previous 2 months.

On the first examination at the emergency department, the patient was conscious and had the symptoms of dyspnea and cyanosis. The respiration rate was $35 / \mathrm{min}$, systolic blood pressure: $100 \mathrm{mmHg}$, diastolic blood pressure: $70 \mathrm{mmHg}$, body temperature: $38.8^{\circ} \mathrm{C}$, pulse: 110/min, and $\mathrm{O}_{2}$ saturation: $88 \%$. On physical examination, sores with white plaques were found in the oral mucosa and pharynx. In both lungs, auscultation revealed rales in the basal regions. Threefour palpable lymph nodules were detected in the submandibular and cervical regions. On neurological examination, loss of strength was observed in all four extremities (3/5). No further defects were found in other organ and system examinations. The venous route was accessed and blood samples were obtained, followed by administration of oxygen $4 \mathrm{lt} / \mathrm{min}$ via a nasal cannule. For the high fever, $1000 \mathrm{mg}$ paracetamol (Perfalgan ${ }^{\circledR} 10 \mathrm{mg} / \mathrm{mL}, 100 \mathrm{~mL}$ ) infusion was administered with $500 \mathrm{cc}$ isotonic $\mathrm{NaCl}$ infusion. Based on a pre-diagnosis of pneumonia, postero-anterior lung radiography was requested. Chest X-Ray revealed consolidation in the basal regions of both lungs (Figure 1). On complete blood count, the white blood cell count was determined as $5400 \mu / \mathrm{L}$. Blood biochemistry did not show any abnormalities, except for Sodium: $127 \mathrm{mmol} / \mathrm{L}$ and Chloride: $88 \mathrm{mmol} / \mathrm{L}$.

Consultation was requested from the Department of Pulmonary Diseases due to the pre-diagnosis of pneumonia with high fever and dyspnea, and from the Department of Ear -Nose and Throat due to plaques in the oral mucosa, dysphagia and hoarseness. Following the consultations, the white plaques in the oral mucosa were diagnosed as oral candidiasis. Upon consultation with the Department of Pulmonary Diseases, computerized tomography of the thorax was performed due to suspicion of lung tumor. Bilateral generalized interstitial involvement was observed in the lungs. No lesion consistent with a mass was detected. Considering all the clinical findings, a clinical state was suggested to be causing pneumonia on the basis of immune suppression, and the Anti-HIV test was requested, with suspected HIV infection. Upon a positive test result, the patient was hospitalized in the intensive care unit with the diagnoses of pneumonia and AIDS. The patient was followed up at the intensive care unit for 27 days and died due to respiratory failure.

\section{Discussion}

In 2003, the Center for Disease Control (CDC) described AIDS disease as the presence of laboratory confirmation of HIV infection and at least one of the indicators of immune deficiency or other complications (Table 1) $(2,6)$

AIDS progresses with non-specific symptoms such as fever, weight loss, malaise and anorexia. In the literature, these patients have rarely been reported to present at emergency departments with severe initial clinical signs and symptoms such as acute idiopathic hemorrhagic pericarditis and myelitis $(4,5)$. Oropharyngeal candidiasis, in particular, must raise suspicion of a clinical state such as HIV, because it indicates an underlying immune suppression (1). In our case in particular, oral candidiasis and hoarseness were present on admission, in addition to non-specific clinical findings. This should be regarded as a warning symptom for physicians working in emergency departments (1).

This case report is of importance in terms of considering AIDS disease and emphasizing the Anti-HIV test in cases presenting at emergency departments with non-specific symptoms, who are suspected of having an immune deficiency. On the other hand, HIV screening tests may not be available in the majority of emergency departments (7). Only the cases with signs or symptoms suggestive of HIV infection or AIDS should be regarded as target patients for screening tests (7). Although the Center for Disease Control and Prevention (CDC) recommends screening for HIV in emergency departments and has described the beneficial aspects of this application, this approach is not adopted in a significant number of institutions (8).

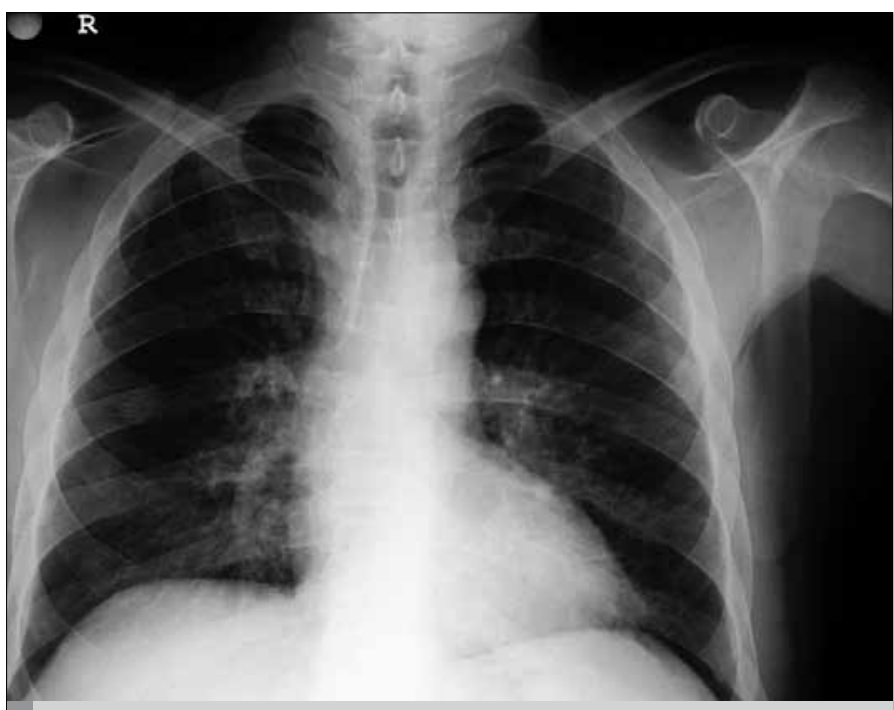

Figure 1. Blateral consolidation on the chest radiograph 
Table 1. AIDS-defining ilnesses

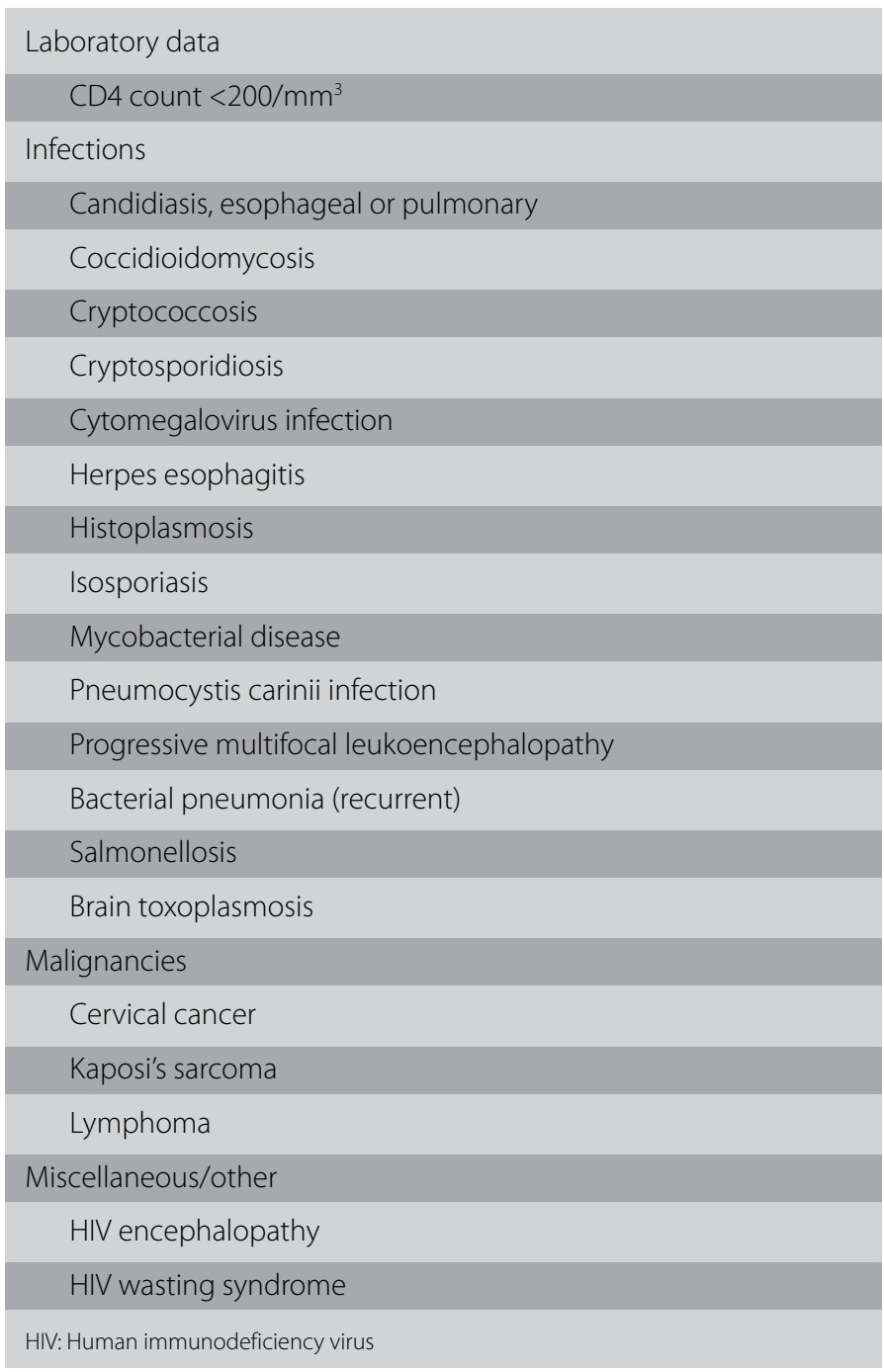

Alteration in the demographic distribution of patients with HIV infection has led to an increase in the number of HIV-positive cases and patients with AIDS and/or AIDS complications presenting at emergency departments.

Since the test results of the Western-Blot technique, which is 99.9\% sensitive and specific for HIV serology, are obtained in one week, it is not appropriate for use in emergency departments; however, tests which yield results in less than one hour are available. Nevertheless, the results of these tests should be further confirmed by the Western-Blot technique.

Symptoms of acute HIV infection are observed in 50\%-90\% of the patients (2). In $75 \%$ of the patients, the diagnosis is missed due to these non-specific symptoms with no accompanying clinical suspicion (9). Furthermore, the suppressed immune response in these patients may lead to insidious progression of clinical disease states such as ischemia or inflammation (9). However, early diagnosis is of utmost importance in terms of initiating early treatment. The main reasons for insufficient use of the Anti-HIV test in emergency departments are time constraints and difficulty in follow-up.

Although AIDS is considered as a complication of HIV infection, it is a more common disease than generally accepted. Symptoms on presentation are non-specific. Therefore, it may be suggested that AIDS cases frequently present at the emergency departments, but diagnosis is missed.

The high number of patients in the emergency departments and the difficulty in explaining the findings with a specific disease cause physicians to miss the diagnosis easily.

\section{Conclusion}

Considering the contribution of early diagnosis, early treatment and choice of appropriate treatment in AIDS disease in decreasing the mortality and morbidity, AIDS is the first disease to be suspected and confirmed in cases presenting to the emergency departments with non-specific symptoms, together with a potential of immune suppression. This case report is significant in terms of alerting Emergency department physicians about AIDS disease.

\section{Conflict of interest}

No conflict of interest was declared by the authors.

\section{References}

1. Tsai SH, Chu SJ, Wu CP, Wang NC. Listerial meningitis in a patient with undiagnosed acquired immunodeficiency syndrome: ampicillin should be added to the empirical antibiotic coverage. Emerg Med J 2006; 23: 50. [CrossRef]

2. Marco CA, Rothman RE. HIV Infection and complications in emergency medicine. Emerg Med Clin N Am 2008; 26: 367-87. [CrossRef]

3. Sağlık İstatistikleri Yıllığı 2010. http://www.saglik.gov.tr/TR/belge/1-13438/saglik-istatistikleri-yilligi-2010.html

4. Park Yl, Sir JJ, Park SW, Kim HT, Lee B, Kwak YK, et al. Acute idiopathic hemorrhagic pericarditis with cardiac tamponade as the initial presentation of acquired immune deficiency syndrome. Yonsei Med J 2010; 51: 273-5. [CrossRef]

5. Garcia-Gubern C, Fuentes CR, Colon-Rolon L, Masvidal D. Spinal cord toxoplasmosis as an unusual presentation of AIDS: case report and review of the literature. Int J Emerg Med 2010; 3: 439-42. [CrossRef]

6. Centers for Disease Control And Prevention. 1993 Revised classification system for HIV infection and expanded surveillance case definition for AIDS among adolescents and adults. MMWR Morb Mort Wkly Rep 1993; 41: 1.

7. White DA, Tran T, Dideum PJ, Vahidnia F, Gordon DM, Ng V, et al. Physician-initiated rapid HIV testing in an urban emergency department: comparison of testing using a point-of-care versus a laboratory model. Ann Emerg Med 2011; 58: 53-9. [CrossRef]

8. White DA, Scribner AN, Schulden JD, Branson BM, Heffelfinger JD. Results of a rapid HIV screening and diagnostic testing program in an urban emergency department. Ann Emerg Med 2009; 54: 56-64. [CrossRef]

9. Kehagias I, Karamanakos SN, Panagiotopoulos S, Giali S, Gogos CA, Kalfarentzos F. A rare case of intussusception leading to the diagnosis of acquired immune deficiency syndrome: a case report. J Med Case Rep 2009; 3: 61. [CrossRef] 